\title{
Steroidal Saponins from Furcraea hexapetala Leaves and Their Phytotoxic Activity
}

\author{
Juan M. Calle, ${ }^{\dagger}$ Andy J. Pérez, ${ }^{\ddagger}$ Ana M. Simonet, ${ }^{\dagger}$ José O. Guerra, $^{\S}$ and Francisco A. Macías* ${ }^{*}{ }^{\dagger}$ \\ ${ }^{\dagger}$ Grupo de Alelopatía, Departamento de Química Orgánica, Instituto de Biomoléculas (INBIO), Facultad de Ciencias, Universidad de \\ Cádiz, C/ República Saharaui, s/n, 11510-Puerto Real (Cádiz), Spain \\ ¥Área Productos Químicos, Unidad de Desarrollo Tecnológico (UDT), Universidad de Concepción, Bío-Bío, Chile \\ ${ }^{\S}$ Departamento de Licenciatura en Química, Facultad de Química y Farmacia, Universidad Central "Marta Abreu" de Las Villas, \\ Carretera a Camajuaní km 5.5, 54830 Santa Clara, Cuba
}

\section{Supporting Information}

ABSTRACT: Four new steroidal saponins (1-4) along with 13 known saponins were isolated from the leaves of Furcraea hexapetala. The new compounds were identified as $(20 R, 22 R, 25 R)-3 \beta$-hydroxy- $5 \alpha$-spirostan-12-one $3-O-\{\alpha$-Lrhamnopyranosyl- $(1 \rightarrow 4)-O-\beta$-D-glucopyranosyl- $(1 \rightarrow 3)-O-[\beta$ D-glucopyranosyl- $(1 \rightarrow 3)-O-\beta$-D-glucopyranosyl- $(1 \rightarrow 2)]-O-\beta$ D-glucopyranosyl- $(1 \rightarrow 4)$ - $O$ - $\beta$-D-galactopyranoside $\} \quad(1)$, (25R)-3 $\beta$-hydroxy-5 $\alpha$-spirost-20(21)-en-12-one 3-O-\{ $\alpha$-Lrhamnopyranosyl- $(1 \rightarrow 4)-O-\beta$-D-glucopyranosyl- $(1 \rightarrow 3)-O-[\beta$ D-glucopyranosyl- $(1 \rightarrow 3)-O-\beta$-D-glucopyranosyl- $(1 \rightarrow 2)]-O-\beta$ D-glucopyranosyl- $(1 \rightarrow 4)-O$ - $\beta$-D-galactopyranoside $\} \quad(2)$, (25R)-5 $\alpha$-spirostan-3 $\beta$-ol 3 - $O$ - $\{\beta$-D-glucopyranosyl- $(1 \rightarrow 2)-O$ $\beta$-D-glucopyranosyl- $(1 \rightarrow 2)-O-\beta$-D-glucopyranosyl- $(1 \rightarrow 4)-O-\beta$ D-galactopyranoside $\}$ (3), and (25R)-5 $\beta$-spirostan-3 $\beta$-ol 3 - $O$ - $\{\beta$-D-glucopyranosyl- $(1 \rightarrow 6)-O-\beta$-D-galactopyranoside $\}$ (4) by spectroscopic analysis, including one- and two-dimensional NMR techniques, mass spectrometry, and chemical methods. The phytotoxicity of the isolated compounds against the standard target species Lactuca sativa was evaluated. Structure-activity relationships for these compounds with respect to phytotoxic effects are discussed.
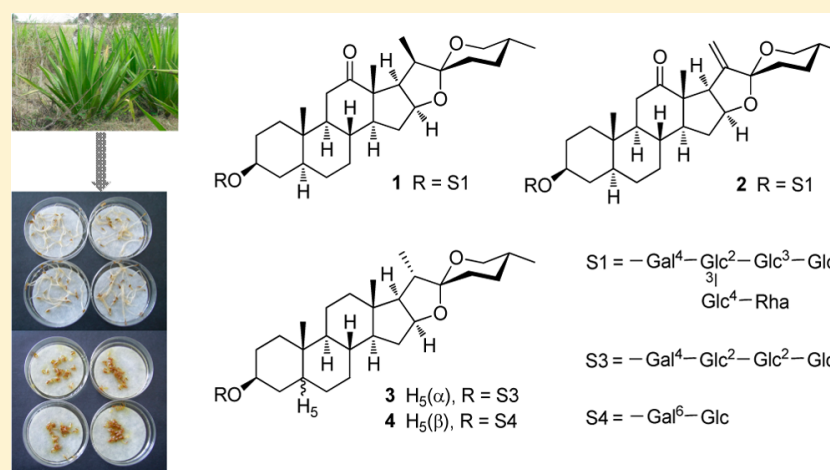

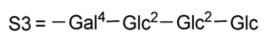
$\mathrm{S} 4=-\left.\mathrm{Ga}\right|^{6}-\mathrm{Glc}$
$\mathrm{T}$ he genus Furcraea belongs to the Agavaceae family, which consists of around 20 species endemic to tropical America and is cultivated mainly in warm climates as ornamental plants. One of these species is Furcraea hexapetala (Jacq.) Urb., an endemic plant from the western region of Cuba, the leaves of which can reach up to two meters in length and are used as a source of fibers. ${ }^{1}$ Steroidal sapogenins were identified from leaves of $F$. hexapetala, with hecogenin and tigogenin being the most prominent. ${ }^{2}$ However, in-depth phytochemical studies on F. hexapetala have not been reported to date. The extracted juice of the leaves of this plant is used by farmers of Cienfuegos Province (Cuba), who spray a diluted solution over plants as a natural pesticide, and this has led to prior studies being carried out. The insecticidal and acaricidal activities of extracts obtained from $F$. hexapetala have been reported recently, with these activities attributed to the presence of saponins. 3,4

As part of current research on the phytochemical study of species from the Agavaceae family, ${ }^{5-8}$ along with the search for phytotoxic natural products, a bioassay-guided isolation of compounds from the leaves of $F$. hexapetala was performed. The isolation and characterization of four new steroidal saponins, named furcrosides A-D (1-4), together with another 13 known steroidal saponins are described. The main isolated compounds were evaluated in a phytotoxicity bioassay. ${ }^{9}$

\section{RESULTS AND DISCUSSION}

Dried and ground leaves of $F$. hexapetala were extracted with $\mathrm{EtOH}-\mathrm{H}_{2} \mathrm{O}$ (7:3). The extract was partitioned in $n-\mathrm{BuOH}-$ $\mathrm{H}_{2} \mathrm{O}$, and the organic phase was subjected to VLC on RP-18 to give nine fractions. In order to evaluate the initial bioactivity of the fractions from the butanol extract, these fractions were assayed on etiolated wheat coleoptiles at 800,400 , and 200 ppm (Figure S41, Supporting Information). This bioassay has been confirmed as an appropriate approach for bioguided isolation, showing a direct correlation with the phytotoxicity of saponins. ${ }^{7,8}$

Multiple separation procedures were carried out on the active fractions (F4 to F9) to provide 17 pure steroidal saponins. Four new steroidal saponins, named furcrosides $\mathrm{A}-\mathrm{D}(\mathbf{1 - 4})$, were isolated along with 13 known steroidal saponins identified as yuccaloesides $\mathrm{C}(5)$ and $\mathrm{B}(6),{ }^{10}$ atroposide E (7), ${ }^{11}$ petunioside $\mathrm{F}(\mathbf{8}){ }^{12}$ chlorogenin-3-O- $\{\alpha$-L-rhamnopyranosyl$(1 \rightarrow 4)-O-\beta$-D-glucopyranosyl- $(1 \rightarrow 3)$ - $O$-[ $\beta$-D-glucopyranosyl$(1 \rightarrow 3)-O-\beta$-D-glucopyranosyl- $(1 \rightarrow 2)]-O-\beta$-D-glucopyranosyl$(1 \rightarrow 4)-O-\beta$-D-galactopyranoside $\} \quad(9),{ }^{13}$ furcreastatin $(\mathbf{1 0}),{ }^{14}$

Received: July 29, 2016

Published: October 31, 2016 


\section{Chart 1}
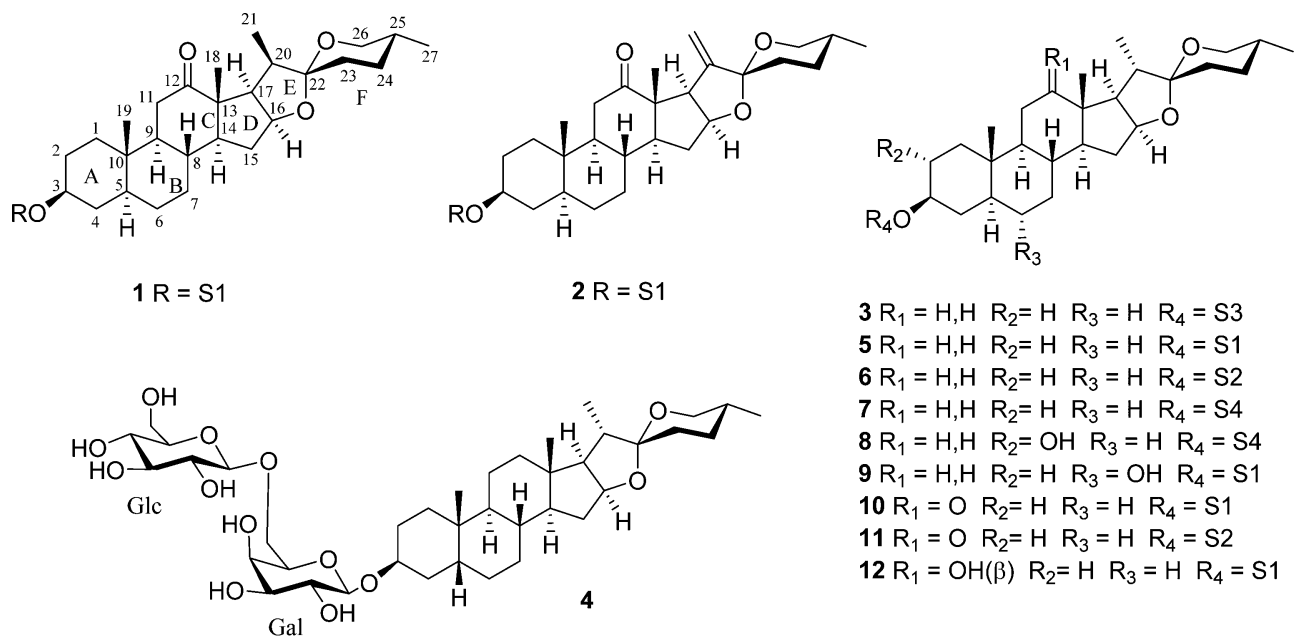

$3 \mathrm{R}_{1}=\mathrm{H}, \mathrm{H} \mathrm{R}_{2}=\mathrm{H} \mathrm{R} \mathrm{R}_{3}=\mathrm{H} \mathrm{R}_{4}=\mathrm{S} 3$

$5 \mathrm{R}_{1}=\mathrm{H}, \mathrm{H} \mathrm{R}_{2}=\mathrm{H} \mathrm{R}_{3}=\mathrm{H} \mathrm{R} \mathrm{R}_{4}=\mathrm{S} 1$

$6 \mathrm{R}_{1}=\mathrm{H}, \mathrm{H} \mathrm{R}_{2}=\mathrm{H} \mathrm{R}_{3}=\mathrm{H} \mathrm{R}_{4}=\mathrm{S} 2$

$7 R_{1}=H, H \quad R_{2}=H R_{3}=H R_{4}=S 4$

$8 \mathrm{R}_{1}=\mathrm{H}, \mathrm{H} \mathrm{R} \mathrm{R}_{2}=\mathrm{OH} \mathrm{R}_{3}=\mathrm{H} \mathrm{R} \mathrm{R}_{4}=\mathrm{S} 4$

$9 \mathrm{R}_{1}=\mathrm{H}, \mathrm{H} \mathrm{R}_{2}=\mathrm{H} \mathrm{R}_{3}=\mathrm{OH} \mathrm{R}_{4}=\mathrm{S} 1$

$10 R_{1}=O R_{2}=H R_{3}=H R_{4}=S 1$

$11 R_{1}=O \quad R_{2}=H R_{3}=H R_{4}=S 2$

$12 \mathrm{R}_{1}=\mathrm{OH}(\beta) \mathrm{R}_{2}=\mathrm{H} \mathrm{R} \mathrm{R}_{3}=\mathrm{H} \mathrm{R} \mathrm{R}_{4}=\mathrm{S} 1$
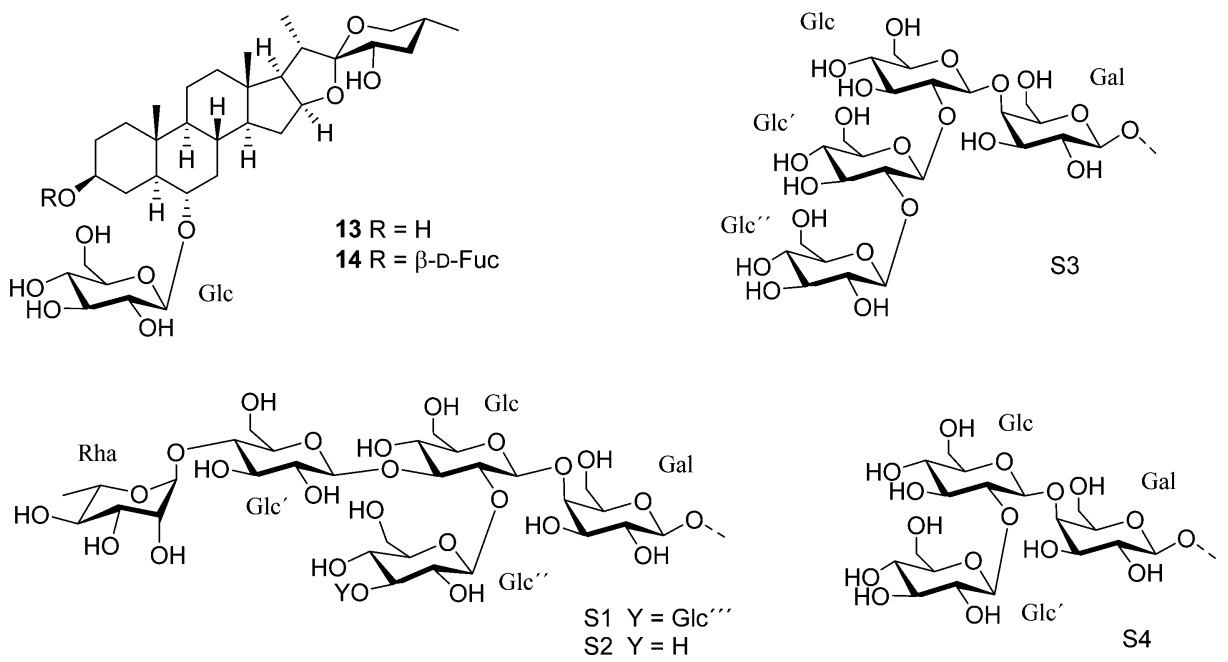

hecogenin-3-O-\{ $\alpha$-L-rhamnopyranosyl- $(1 \rightarrow 4)-O-\beta$-D-glucopyranosyl- $(1 \rightarrow 3)-O$-[ $\beta$-D-glucopyranosyl- $(1 \rightarrow 2)]-O-\beta$-D-glucopyranosyl- $(1 \rightarrow 4)-O-\beta$-D-galactopyranoside $\}(11),{ }^{15}$ rockogenin-3$O-\{\alpha$-L-rhamnopyranosyl- $(1 \rightarrow 4)-O-\beta$-D-glucopyranosyl- $(1 \rightarrow$ 3)- $O$ - $[\beta$-D-glucopyranosyl- $(1 \rightarrow 3)-O-\beta$-D-glucopyranosyl- $(1 \rightarrow$ $2)]-O-\beta$-D-glucopyranosyl- $(1 \rightarrow 4)-O-\beta$-D-galactopyranoside $\}$ $(\mathbf{1 2}),{ }^{15}$ smilagenin-3-O-[ $\beta$-D-glucopyranosyl- $(1 \rightarrow 3)-O-\beta$-D-galactopyranoside $]{ }^{16}$ agameroside-1 (13), ${ }^{17}$ chlorogenin-3-O- $[\beta$ D-glucopyranosyl]-6-O-[ $\beta$-D-glucopyranoside $],{ }^{18}$ cantalasaponin- $1,{ }^{19}$ and chrysogenin $3-O-[\beta$-D-fucopyranosyl $]-6-O-[\beta$-Dglucopyranoside] $(\mathbf{1 4}) .^{20}$

The structures of the new compounds were elucidated on the basis of spectroscopic data obtained by $1 \mathrm{D}$ and 2D NMR experiments (Tables 1 and 2), HRTOFESIMS spectra, and acid hydrolysis. The absolute configurations of the sugar components were determined by a slight modification of the method reported by Tanaka et al. ${ }^{21}$ Briefly, sugars were converted into the thiazolidine derivatives and then into the arylthiocarbamate using L-cysteine methyl ester and $o$-tolylisothiocyanate. The reaction mixture was then directly analyzed by reversed-phase HPLC-UV, and the retention times $\left(t_{\mathrm{R}}\right)$ were compared with values obtained for derivatives of authentic sugar samples (Dglucose, D-galactose, and L-rhamnose) with D- and L-cysteine methyl ester. In this way, D-galactose, D-glucose, and Lrhamnose were identified.
Compound 1 was isolated as an amorphous powder and exhibited a deprotonated molecular ion at $\mathrm{m} / z$ 1385.6241 ([M $-\mathrm{H}]^{-}$, calcd 1385.6225) in the negative-ion mode HRTOFESIMS, and this corresponded to a molecular formula of $\mathrm{C}_{63} \mathrm{H}_{102} \mathrm{O}_{33}$. This molecular formula is identical to that of the main compound isolated from $F$. hexapetala leaves, furcreastatin (10), indicating that these two compounds are isomers. The ${ }^{1} \mathrm{H}$ NMR spectrum of 1 contained six anomeric proton signals at $\delta$ $4.82(\mathrm{~d}, J=7.5 \mathrm{~Hz}), 5.08(\mathrm{~d}, J=7.7 \mathrm{~Hz}), 5.10(\mathrm{~d}, J=8.0 \mathrm{~Hz})$, $5.16(\mathrm{~d}, J=7.8 \mathrm{~Hz}), 5.52(\mathrm{~d}, J=7.6 \mathrm{~Hz})$, and $5.75(\mathrm{br} \mathrm{s})$, and these showed correlations in the HSQC spectrum with carbons resonating at $\delta 102.4,105.6,104.7,104.2,104.0$, and 102.6, respectively. Individual sugar units were identified by a combination of one- and two-dimensional NMR experiments, and their absolute configurations were determined under the conditions described above. The sequence of the sugars in the chain was established by means of interglycosidic HMBC/ ROESY correlations as a glycosidic chain formed by six sugar units identical to that in compound $\mathbf{1 0 .}$

The ${ }^{1} \mathrm{H}$ NMR spectrum of $\mathbf{1}$ showed a typical signal pattern for a spirostane aglycone, with two singlet signals for tertiary methyl groups at $\delta 1.19$ and 0.65 and two doublet signals for secondary methyl groups at $1.23(\mathrm{~d}, J=7.9 \mathrm{~Hz})$ and $0.67(\mathrm{~d}, J$ $=6.3 \mathrm{~Hz}$ ). The ${ }^{1} \mathrm{H}$ and ${ }^{13} \mathrm{C}$ NMR signal assignments for the aglycone were made through an analysis of the correlations 
Table $1 .{ }^{13} \mathrm{C}$ and ${ }^{1} \mathrm{H}$ NMR Spectroscopic Data $(J$ in $\mathrm{Hz})$ for the Aglycone Moieties of Compounds 1-4 (Pyridine- $\left.d_{5}\right)^{c}$

\begin{tabular}{|c|c|c|c|c|c|c|c|c|}
\hline \multirow[b]{2}{*}{ position } & \multicolumn{2}{|r|}{ furcroside A $(\mathbf{1})^{a}$} & \multicolumn{2}{|r|}{ furcroside B $(2)^{b}$} & \multicolumn{2}{|r|}{ furcroside $C(3)^{b}$} & \multicolumn{2}{|r|}{ furcroside $\mathrm{D}(4)^{b}$} \\
\hline & $\delta_{\mathrm{C}}$ & $\delta \delta_{\mathrm{H}}$ & $\delta_{\mathrm{C}}$ & $\delta \delta_{\mathrm{H}}$ & $\delta_{\mathrm{C}}$ & $\delta \delta_{\mathrm{H}}$ & $\delta_{\mathrm{C}}$ & $\delta \delta_{\mathrm{H}}$ \\
\hline $1_{\mathrm{ax}}$ & 36.7 & $0.69 \mathrm{~m}$ & 36.6 & $0.69(\mathrm{o})^{d}$ & 37.1 & $0.77 \mathrm{~m}$ & 31.0 & $1.66(\mathrm{o})$ \\
\hline $1_{\text {eq }}$ & & $1.29 \mathrm{~m}$ & & $1.27 \mathrm{~m}$ & & $1.49(\mathrm{o})$ & & $1.47(\mathrm{o})$ \\
\hline $2 \mathrm{ax}$ & 29.6 & $1.54(\mathrm{o})$ & 29.6 & $1.54(\mathrm{o})$ & 30.0 & $1.62 \mathrm{~m}$ & 27.0 & $1.53(\mathrm{o})$ \\
\hline $2_{\text {eq }}$ & & $1.97 \mathrm{~m}$ & & $1.96 \mathrm{~m}$ & & $2.02(\mathrm{o})$ & & $1.98 \mathrm{~m}$ \\
\hline 3 & 77.1 & $3.84 \mathrm{~m}$ & 77.1 & $3.84 \mathrm{~m}$ & 77.3 & $3.91 \mathrm{~m}$ & 74.4 & $4.38(\mathrm{o})$ \\
\hline $4_{\mathrm{ax}}$ & 34.6 & $1.32 \mathrm{~m}$ & 34.6 & $1.31(\mathrm{o})$ & 34.8 & $1.34 \mathrm{~m}$ & 30.7 & 1.78 br d (12.4) \\
\hline $4_{\text {eq }}$ & & 1.77 br d (12.0) & & 1.77 br d (12.3) & & $1.77(\mathrm{o})$ & & $1.66(\mathrm{o})$ \\
\hline 5 & 44.4 & $0.82(\mathrm{o})$ & 44.4 & $0.83(\mathrm{o})$ & 44.6 & $\begin{array}{l}0.88 \text { dddd }(12.2,12.2,2.9 \\
2.9)\end{array}$ & 36.8 & $1.94(\mathrm{o})$ \\
\hline $6_{\mathrm{ax}}$ & 28.6 & $1.10(2 \mathrm{H})(\mathrm{o})$ & 28.5 & $1.09(2 \mathrm{H})(\mathrm{o})$ & 28.9 & $1.04 \mathrm{~m}$ & 27.0 & $1.69 \mathrm{~m}$ \\
\hline $6_{\mathrm{eq}}$ & & & & & & $1.08 \mathrm{~m}$ & & $1.03(\mathrm{o})$ \\
\hline $7_{\mathrm{ax}}$ & 31.6 & $0.73 \mathrm{~m}$ & 31.6 & $0.73 \mathrm{~m}$ & 32.4 & $0.76 \mathrm{~m}$ & 26.7 & $\begin{array}{l}0.92 \text { dddd }(13.4,13.4,13.4 \text {, } \\
4.4)\end{array}$ \\
\hline $7_{\text {eq }}$ & & $1.50(\mathrm{o})$ & & $1.52(\mathrm{o})$ & & $1.49(\mathrm{o})$ & & $1.24(\mathrm{o})$ \\
\hline 8 & 34.2 & $1.69(\mathrm{o})$ & 34.7 & $1.69(\mathrm{o})$ & 35.2 & $1.38(\mathrm{o})$ & 35.5 & $1.46(\mathrm{o})$ \\
\hline 9 & 55.8 & $0.84(\mathrm{o})$ & 55.5 & $0.86(\mathrm{o})$ & 54.4 & 0.47 ddd $(12.3,11.6,4.1)$ & 40.2 & $1.25(\mathrm{o})$ \\
\hline 10 & 36.2 & & 36.2 & & 35.8 & & 35.2 & \\
\hline $11_{\mathrm{ax}}$ & 37.8 & $2.36 \mathrm{dd}(13.5,13.4)$ & 37.7 & $2.36 \mathrm{dd}(14.6,13.8)$ & 21.2 & $\begin{array}{l}1.16 \text { dddd (13.2, 12.8, } 12.3 \text {, } \\
3.8)\end{array}$ & 21.1 & $1.13(\mathrm{o})$ \\
\hline $11_{\mathrm{eq}}$ & & $2.15 \mathrm{dd}(13.4,4.4)$ & & $2.20 \mathrm{dd}(14.6,4.5)$ & & $1.36(\mathrm{o})$ & & $1.32 \mathrm{~m}$ \\
\hline $12_{\mathrm{ax}}$ & 213.0 & & 212.5 & & 40.1 & $1.01(\mathrm{o})$ & 40.3 & $1.02(\mathrm{o})$ \\
\hline $12_{\mathrm{eq}}$ & & & & & & $1.63(0)$ & & $1.64(\mathrm{o})$ \\
\hline 13 & 56.2 & & 56.9 & & 40.7 & & 40.9 & \\
\hline 14 & 57.4 & $1.22(\mathrm{o})$ & 55.9 & $1.33(\mathrm{o})$ & 56.4 & $0.99(\mathrm{o})$ & 56.4 & $1.04(\mathrm{o})$ \\
\hline $15_{\mathrm{ax}}$ & 31.4 & $1.59 \mathrm{~m}$ & 32.0 & $1.63(\mathrm{o})$ & 32.1 & $1.38(\mathrm{o})$ & 32.1 & 1.39 ddd $(13.5,12.2,6.3)$ \\
\hline $15_{\text {eq }}$ & & $\begin{array}{l}2.06 \text { ddd }(13.4,7.2 \text {, } \\
7.2)\end{array}$ & & 2.13 ddd $(12.5,7.3,7.3)$ & & $2.00(\mathrm{o})$ & & 2.02 ddd $(12.4,5.8,7.7)$ \\
\hline 16 & 79.7 & $4.51(\mathrm{o})$ & 79.9 & $4.65(0)$ & 81.1 & $4.53(\mathrm{o})$ & 81.2 & 4.60 ddd $(7.9,7.9,6.2)$ \\
\hline 17 & 53.6 & $2.87 \mathrm{dd}(9.2,6.5)$ & 52.5 & 3.64 ddd $(7.6,2.0,2.0)$ & 63.0 & $1.77 \mathrm{dd}(6.8,8.4)$ & 63.1 & $1.84 \mathrm{dd}(6.8,8.1)$ \\
\hline 18 & 16.1 & $1.19 \mathrm{~s}$ & 15.0 & $0.99 \mathrm{~s}$ & 16.6 & $0.80 \mathrm{~s}$ & 16.5 & $0.79 \mathrm{~s}$ \\
\hline 19 & 11.7 & $0.65 \mathrm{~s}$ & 11.7 & $0.64 \mathrm{~s}$ & 12.3 & $0.62 \mathrm{~s}$ & 23.8 & $0.79 \mathrm{~s}$ \\
\hline 20 & 46.4 & 2.81 quin. (8.1) & 151.6 & & 41.9 & $1.93 \mathrm{dq}(7.0,6.8)$ & 42.0 & $1.94 \mathrm{dq}(6.9,6.8)$ \\
\hline $21_{\mathrm{a}}$ & 12.2 & $1.23 \mathrm{~d}(7.9)$ & 110.3 & 5.39 br s & 15.0 & $1.11 \mathrm{~d}(7.0)$ & 15.0 & $1.14 \mathrm{~d}(6.9)$ \\
\hline $21_{b}$ & & & & 5.54 br s & & & & \\
\hline 22 & 108.4 & & 107.1 & & 109.2 & & 109.2 & \\
\hline $23_{\mathrm{ax}}$ & 31.0 & $1.69(2 \mathrm{H})(\mathrm{o})$ & 31.7 & $\begin{array}{l}1.88 \text { ddd }(13.3,13.2 \text {, } \\
4.9)\end{array}$ & 31.8 & $1.63 \mathrm{~m}$ & 31.8 & $1.64(\mathrm{o})$ \\
\hline $23_{\mathrm{eq}}$ & & & & $1.67(\mathrm{o})$ & & $1.68 \mathrm{~m}$ & & $1.68(\mathrm{o})$ \\
\hline 24 & 28.9 & $1.57(2 \mathrm{H})(\mathrm{o})$ & 29.0 & $1.58(2 \mathrm{H})(\mathrm{o})$ & 29.2 & $1.54(2 \mathrm{H})(\mathrm{o})$ & 29.2 & $1.55(2 \mathrm{H})(\mathrm{o})$ \\
\hline 25 & 30.8 & $1.58(\mathrm{o})$ & 31.5 & $1.66(\mathrm{o})$ & 30.6 & $1.55(\mathrm{o})$ & 30.6 & $1.56(\mathrm{o})$ \\
\hline $26_{\mathrm{ax}}$ & 68.1 & $3.56(2 \mathrm{H})(\mathrm{o})$ & 67.6 & $3.52 \mathrm{dd}(11.1,11.1)$ & 66.8 & $3.48 \mathrm{dd}(10.6,10.6)$ & 66.8 & $3.50 \mathrm{dd}(10.6,10.5)$ \\
\hline $26_{\text {eq }}$ & & & & $3.57 \mathrm{dd}(11.1,4.3)$ & & $3.56 \mathrm{dd}(10.6,3.7)$ & & $3.58 \mathrm{dd}(10.6,3.6)$ \\
\hline 27 & 17.3 & $0.67 \mathrm{~d}(6.3)$ & 17.3 & $0.68 \mathrm{~d}(6.5)$ & 17.3 & $0.67 \mathrm{~d}(5.7)$ & 17.3 & $0.67 \mathrm{~d}(5.4)$ \\
\hline
\end{tabular}

${ }^{a}$ Data were measured at $150 \mathrm{MHz}\left({ }^{13} \mathrm{C}\right.$ NMR $)$ and $600 \mathrm{MHz}\left({ }^{1} \mathrm{H}\right.$ NMR $) .{ }^{b}$ Data were measured at $125 \mathrm{MHz}\left({ }^{13} \mathrm{C}\right.$ NMR $)$ and $600 \mathrm{MHz}\left({ }^{1} \mathrm{H} \mathrm{NMR}\right)$. ${ }^{c}$ Assignments were confirmed by ${ }^{1} \mathrm{H}-{ }^{1} \mathrm{H}$-COSY, 2D-TOCSY, HSQC, HSQC-TOCSY, and HMBC experiments. ${ }^{d}$ o: overlapped with other signals.

determined in HSQC, HMBC, ${ }^{1} \mathrm{H}-{ }^{1} \mathrm{H}$ COSY, and 2D-TOCSY experiments.

The presence of a carbonyl group was suggested by the signal at $\delta 213.0$ in the ${ }^{13} \mathrm{C}$ NMR spectrum. This showed HMBC correlations with protons at $\delta 2.36$ and 2.15 (2H-11), $2.87(\mathrm{H}-$ $17)$, and 1.19 ( $\mathrm{H}-18)$ of compound 1 , consistent with its location at C-12. Likewise, the sugar chain attached at C-3 of the aglycone moiety was established by correlation of the carbon signal at $\delta 77.1$ (C-3) in the HMBC spectrum. Although the functionalization of the aglycone was shown to be the same as that in compound 10, significant differences were observed in the spectroscopic data, thus indicating that the two compounds are diastereoisomers.
As in furcreastatin (10), the $25 R$ configuration for compound 1 was deduced according to Agrawal's rule, which establishes a $25 R$ configuration when the difference between the chemical shifts of geminal protons in the methylene groups $\mathrm{H}_{2}-23, \mathrm{H}_{2}$ 24, and $\mathrm{H}_{2}-26\left(\Delta_{\mathrm{ab}}=\delta_{\mathrm{a}}-\delta_{\mathrm{b}}\right)$ is less than $0.20 .^{22}$ Moreover, the typical $\mathrm{A} / \mathrm{B}, \mathrm{B} / \mathrm{C}$, and $\mathrm{C} / \mathrm{D}$ "trans" and $\mathrm{D} / \mathrm{E}$ "cis" junctions for spirostanes were determined by an exhaustive study of correlations in the 2D-ROESY experiment. Major differences in the chemical shifts compared with compound $\mathbf{1 0}$ were observed for the E/F rings, especially the notable deshielding of $\mathrm{H}-20(\delta$ 2.81) in compound 1. A 1D-ROESY spectrum acquired by the selective excitation of the proton at $\delta 4.51(\mathrm{H}-$ 16) showed correlations with $\mathrm{H}-17 / \mathrm{H}-15 \alpha$, which is consistent with an " $\alpha$ " orientation of H-16. Likewise, the effects observed 
Table 2. ${ }^{13} \mathrm{C}$ and ${ }^{1} \mathrm{H}$ NMR Spectroscopic Data $(J$ in $\mathrm{Hz})$ of the Sugar Portions of Compounds $1-4\left(\text { Pyridine- } d_{5}\right)^{c \text {, }}$

\begin{tabular}{|c|c|c|c|c|c|c|c|c|}
\hline \multirow[b]{2}{*}{ position } & \multicolumn{2}{|r|}{ furcroside A $(1)^{a}$} & \multicolumn{2}{|c|}{ furcroside B $(2)^{b}$} & \multicolumn{2}{|r|}{ furcroside $\mathrm{C}(3)^{b}$} & \multicolumn{2}{|r|}{ furcroside $\mathrm{D}(4)^{b}$} \\
\hline & $\delta_{\mathrm{C}}$ & $\delta \delta_{\mathrm{H}}$ & $\delta_{\mathrm{C}}$ & $\delta \delta_{\mathrm{H}}$ & $\delta_{\mathrm{C}}$ & $\overline{\delta_{\mathrm{H}}}$ & $\delta_{\mathrm{C}}$ & $\overline{\delta_{\mathrm{H}}}$ \\
\hline & & $\beta$-D-Gal & & $\beta$-D-Gal & & $\beta$-D-Gal & & $\beta$-D-Gal \\
\hline 1 & 102.4 & $4.82 \mathrm{~d}(7.5)$ & 102.4 & $4.84 \mathrm{~d}(7.6)$ & 102.3 & $4.88 \mathrm{~d}(7.7)$ & 103.8 & $4.77 \mathrm{~d}(7.7)$ \\
\hline 2 & 73.1 & $4.39(\mathrm{o})^{d}$ & 73.1 & $4.38 \mathrm{dd}(9.5,7.6)$ & 73.2 & 4.44 ddd $(10.0,7.7,4.3)$ & 72.6 & $4.43 \mathrm{dd}(7.7,9.6)$ \\
\hline 3 & 75.6 & 4.09 (o) & 75.6 & $4.08(\mathrm{o})$ & 75.6 & $4.09(\mathrm{o})$ & 75.1 & $4.08 \mathrm{dd}(9.6,3.5)$ \\
\hline 4 & 79.9 & $4.56 \mathrm{br} \mathrm{s}$ & 79.7 & 4.55 br d (3.0) & 80.8 & $4.56 \mathrm{br} \mathrm{d}(3.3)$ & 70.0 & 4.46 br d (3.5) \\
\hline 5 & 75.5 & $3.97(\mathrm{o})$ & 75.5 & $3.98(\mathrm{o})$ & 75.1 & $4.01(\mathrm{o})$ & 74.6 & $4.14 \operatorname{ddd}(6.2,6.2,1.2)$ \\
\hline \multirow[t]{3}{*}{6} & 60.6 & $4.17(\mathrm{o})$ & 60.6 & $4.20(\mathrm{o})$ & 60.5 & $4.23(\mathrm{o})$ & 69.5 & $4.43 \mathrm{~m}$ \\
\hline & & 4.64 br d (8.2) & & $4.64(\mathrm{o})$ & & 4.75 ddd $(10.2,10.2,7.5)$ & & $4.66 \mathrm{dd}(10.7,5.7)$ \\
\hline & & $\beta$-D-Glc & & $\beta$-D-Glc & & $\beta$-D-Glc & & $\beta$-D-Glc \\
\hline 1 & 104.7 & $5.10 \mathrm{~d}(8.0)$ & 104.7 & $5.11 \mathrm{~d}(7.9)$ & 105.0 & $5.11 \mathrm{~d}(7.7)$ & 105.1 & $5.07 \mathrm{~d}(7.8)$ \\
\hline 2 & 80.8 & $4.30 \mathrm{dd}(8.0,8.5)$ & 80.8 & $4.30 \mathrm{dd}(7.9,8.8)$ & 85.8 & $4.12 \mathrm{dd}(7.7,8.6)$ & 75.2 & $4.06 \mathrm{dd}(7.8,8.6)$ \\
\hline 3 & 88.1 & $4.10(\mathrm{o})$ & 88.1 & $4.09 \mathrm{dd}(8.8,8.7)$ & 78.3 & $4.21(\mathrm{o})$ & 78.5 & $4.24(\mathrm{o})$ \\
\hline 4 & 70.6 & $3.71 \mathrm{dd}(8.5,8.5)$ & 70.6 & $3.72 \mathrm{dd}(8.7,9.4)$ & 71.8 & $4.20(\mathrm{o})$ & 71.7 & $4.24(\mathrm{o})$ \\
\hline 5 & 77.4 & $3.78(\mathrm{o})$ & 77.4 & $3.78(\mathrm{o})$ & 78.1 & $3.94 \mathrm{~m}$ & 78.4 & $3.92 \mathrm{ddd}(8.5,5.4,2.5)$ \\
\hline \multirow[t]{3}{*}{6} & 62.9 & $3.96(\mathrm{o})$ & 62.9 & $3.96(\mathrm{o})$ & 63.2 & $4.09(\mathrm{o})$ & 62.7 & $4.34(\mathrm{o})$ \\
\hline & & $4.41(\mathrm{o})$ & & $4.41(\mathrm{o})$ & & $4.60 \mathrm{dd}(10.2 ; 6.2)$ & & 4.49 br d (11.4) \\
\hline & & $\beta$-D-Glc' & & $\beta$-D-Glc' & & $\beta$-D-Glc' & & \\
\hline 1 & 104.2 & $5.16 \mathrm{~d}(7.8)$ & 104.2 & $5.16 \mathrm{~d}(7.8)$ & 106.2 & $5.14 \mathrm{~d}(6.9)$ & & \\
\hline 2 & 75.6 & $3.95 \mathrm{dd}(7.8,8.2)$ & 75.6 & $3.95 \mathrm{dd}(7.8,8.7)$ & 87.2 & $4.04 \mathrm{dd}(6.9,7.7)$ & & \\
\hline 3 & 76.4 & $4.06 \mathrm{dd}(9.8,9.0)$ & 76.4 & $4.05 \mathrm{dd}(9.0,8.7)$ & 68.4 & $4.08(\mathrm{o})$ & & \\
\hline 4 & 78.0 & $4.33(\mathrm{o})$ & 78.0 & $4.32 \mathrm{dd}(9.0,8.0)$ & 75.4 & $4.11(\mathrm{o})$ & & \\
\hline 5 & 77.2 & $3.77(\mathrm{o})$ & 77.2 & $3.77(\mathrm{o})$ & 78.4 & 3.72 ddd $(9.6,2.9,2.7)$ & & \\
\hline \multirow[t]{3}{*}{6} & 61.0 & $4.03(\mathrm{o})$ & 61.1 & $4.03(\mathrm{o})$ & 61.3 & $4.24(\mathrm{o})$ & & \\
\hline & & $4.20(\mathrm{o})$ & & $4.20(\mathrm{o})$ & & $4.48 \mathrm{~m}$ & & \\
\hline & & $\beta$-D-Glu" & & $\beta$-D-Glu" & & $\beta$-D-Glu" & & \\
\hline 1 & 104.0 & $5.52 \mathrm{~d}(7.6)$ & 104.0 & $5.52 \mathrm{~d}(7.7)$ & 105.4 & $5.22 \mathrm{~d}(7.7)$ & & \\
\hline 2 & 74.7 & $4.04(\mathrm{o})$ & 74.7 & $4.05(\mathrm{o})$ & 78.6 & $4.00 \mathrm{dd}(7.7,8.6)$ & & \\
\hline 3 & 88.0 & $4.02 \mathrm{dd}(9.2,8.6)$ & 88.1 & $4.02 \mathrm{dd}(9.0,7.8)$ & 78.2 & $4.21 \mathrm{dd}(8.6,9.6)$ & & \\
\hline 4 & 69.3 & $4.06(\mathrm{o})$ & 69.3 & $4.06(\mathrm{o})$ & 71.6 & $4.15 \mathrm{dd}(9.6,9.1)$ & & \\
\hline 5 & 77.9 & $3.76(\mathrm{o})$ & 77.9 & $3.76(\mathrm{o})$ & 75.5 & $4.01(\mathrm{o})$ & & \\
\hline \multirow[t]{3}{*}{6} & 62.0 & $4.23(\mathrm{o})$ & 62.0 & $4.24(\mathrm{o})$ & 62.5 & 4.28 br d $(12.0)$ & & \\
\hline & & $4.40(\mathrm{o})$ & & $4.41(\mathrm{o})$ & & $4.51 \mathrm{~m}$ & & \\
\hline & & $\beta$-D-Glu"' & & $\beta$-D-Glu"' & & & & \\
\hline 1 & 105.6 & $5.08 \mathrm{~d}(7.7)$ & 105.6 & $5.07 \mathrm{~d}(7.8)$ & & & & \\
\hline 2 & 75.3 & $3.98(\mathrm{o})$ & 75.3 & $3.98 \mathrm{dd}(8.5,7.8)$ & & & & \\
\hline 3 & 78.0 & $4.15 \mathrm{dd}(8.5,9.4)$ & 78.1 & $4.15(\mathrm{o})$ & & & & \\
\hline 4 & 71.5 & $4.12(\mathrm{o})$ & 71.5 & $4.13(\mathrm{o})$ & & & & \\
\hline 5 & 78.5 & 3.88 ddd $(9.0,6.2,2.1)$ & 78.5 & $3.87 \mathrm{~m}$ & & & & \\
\hline \multirow[t]{3}{*}{6} & 62.4 & $4.22(\mathrm{o})$ & 62.5 & $4.23(\mathrm{o})$ & & & & \\
\hline & & $4.45(\mathrm{o})$ & & $4.46(\mathrm{o})$ & & & & \\
\hline & & $\alpha$-L-Rha & & $\alpha$-L-Rha & & & & \\
\hline 1 & 102.6 & $5.75 \mathrm{br} \mathrm{s}$ & 102.6 & $5.76 \mathrm{br} \mathrm{s}$ & & & & \\
\hline 2 & 72.5 & $4.59 \mathrm{br} \mathrm{s}$ & 72.5 & $4.61 \mathrm{br} \mathrm{s}$ & & & & \\
\hline 3 & 72.7 & $4.51 \mathrm{br} \mathrm{d}(7.2)$ & 72.7 & 4.50 br d $(9.0)$ & & & & \\
\hline 4 & 73.9 & $4.31 \mathrm{dd}(7.2,8.6)$ & 73.9 & $4.30(\mathrm{o})$ & & & & \\
\hline 5 & 70.3 & $4.90 \mathrm{dq}(6.2,8.6)$ & 70.4 & $4.91(\mathrm{o})$ & & & & \\
\hline 6 & 18.5 & $1.67 \mathrm{~d}(6.2)$ & 18.5 & $1.67 \mathrm{~d}(6.2)$ & & & & \\
\hline
\end{tabular}

${ }^{a}$ Data were measured at $150 \mathrm{MHz}\left({ }^{13} \mathrm{C} \mathrm{NMR}\right)$ and $600 \mathrm{MHz}\left({ }^{1} \mathrm{H} \mathrm{NMR}\right) .{ }^{b}$ Data were measured at $125 \mathrm{MHz}\left({ }^{13} \mathrm{C}\right.$ NMR $)$ and $600 \mathrm{MHz}\left({ }^{1} \mathrm{H} \mathrm{NMR}\right)$. ${ }^{c}$ Assignments were confirmed by ${ }^{1} \mathrm{H}-{ }^{1} \mathrm{H}$-COSY, 2D-TOCSY, HSQC, HSQC-TOCSY, and HMBC experiments. ${ }^{d}$ o: overlapped with other signals.

in 1 D-ROESY between $\mathrm{H}-16$ and $\mathrm{H}-26_{\mathrm{ax}}$ suggested an " $\mathrm{R}$ " configuration for the spiroketalic carbon C-22, as in furcreastatin (10). An additional correlation was observed between $\mathrm{H}-16$ and $\mathrm{H}-20$, which might suggest the epimerization of C-20. This inference was confirmed by the 1D-ROESY spectra acquired after the selective excitations of signals at $\delta$ $2.81(\mathrm{H}-20)$ and $1.23(\mathrm{Me}-21)$. In this way, correlations between $\mathrm{H}-20$ and $\mathrm{H}-16 / \mathrm{H}-17$ indicated an " $\alpha$ " orientation for $\mathrm{H}-20$, while correlations between the methyl group at $\mathrm{H}-21$ and
$\mathrm{H}-18 / \mathrm{H}-23$ confirmed a " $\beta$ " disposition for this methyl group and an " $R$ " configuration for C-20 (Figure 1). Spirostane saponins with different configurations at C-20 and C-22 were synthesized by Tobari et al., ${ }^{23}$ and chemical shifts greater than 2.47 ppm were observed for the H-20 signal, which means that $\mathrm{H}-20$ and the oxygen atom of the $\mathrm{F}$ ring were in a relative cis disposition. This situation was consistent with the experimental data obtained for compound $\mathbf{1}$. 


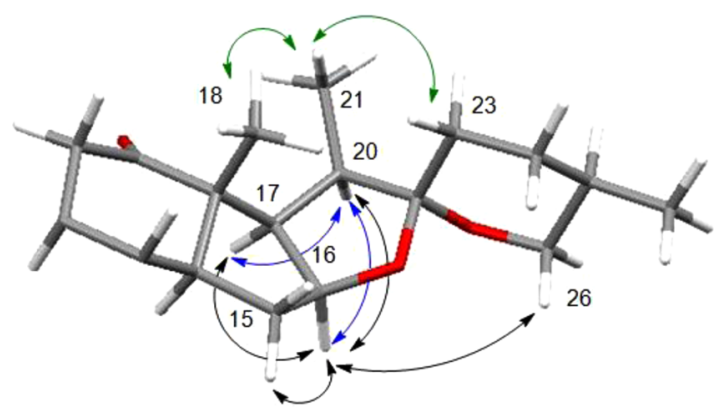

Figure 1. Key NOE correlations that show the $\beta$-orientation of methyl-21 for compound 1. Correlations observed from the $1 \mathrm{D}$ ROESY spectrum performed by selective excitation of proton $\mathrm{H}-16(\delta$ 4.51, black arrows), $\mathrm{H}-20$ ( $\delta 2.81$, blue arrows), and $\mathrm{H}-21$ ( $\delta 1.23$, green arrows).

Consequently, the aglycone moiety of compound $\mathbf{1}$ was elucidated as 20 -isohecogenin. ${ }^{24}$ The $(20 R)$ isomers of spirostane sapogenins have usually been considered as "unnatural", and they are often obtained by synthetic methods. However, in the literature, the $(20 R, 22 S)$ configuration is noted for brodioside $\mathrm{B}$, a saponin isolated from Brodiaea californica tubers, ${ }^{25}$ and for two steroids from Dracaena cambodiana. ${ }^{26}$ To the best of our knowledge, compound $\mathbf{1}$ is the first $(20 R, 22 R)$-spirostanol glycoside to have been isolated from a natural source. Thus, the structure of $\mathbf{1}$ was characterized as $(20 R, 22 R, 25 R)-3 \beta$-hydroxy- $5 \alpha$-spirostan-12one 3-O-\{ $\alpha$-L-rhamnopyranosyl- $(1 \rightarrow 4)-O-\beta$-D-glucopyranosyl$(1 \rightarrow 3)$ - $O$ - $[\beta$-D-glucopyranosyl- $(1 \rightarrow 3)-O-\beta$-D-glucopyranosyl$(1 \rightarrow 2)]-O-\beta$-D-glucopyranosyl- $(1 \rightarrow 4)-O-\beta$-D-galactopyranoside\}. This compound has not been reported previously, and it has been named furcroside $A$.

Compound 2 was obtained as a white, amorphous powder. The molecular formula was established as $\mathrm{C}_{63} \mathrm{H}_{100} \mathrm{O}_{33}$ by HRTOFESIMS at $m / z 1383.6047\left([\mathrm{M}-\mathrm{H}]^{-}\right.$, calcd 1383.6069). The NMR features were typical of a spirostane saponin, with signals from the sugar portion almost superimposable on those of compound 1. Scrutiny of the 1DTOCSY, 1D-ROESY, and HMBC spectra confirmed a sugar chain identical to that of furcroside A (1) and furcreastatin (10). Relative to the aglycone moiety, most of the differences in chemical shifts between compounds 1 and $\mathbf{2}$ were observed for rings $\mathrm{D}$ and $\mathrm{E}$. The ${ }^{1} \mathrm{H}$ NMR spectrum of 2 contained two singlet signals for tertiary methyl groups at $\delta 0.99$ and 0.64 and only one doublet signal for a secondary methyl group at $\delta 0.68$ $(\mathrm{d}, J=6.5 \mathrm{~Hz}$ ), which suggested the lack of a methyl group. Two broad singlet signals were observed at $\delta 5.54$ and 5.39, typical of geminal olefinic protons, and these showed correlations in the HSQC spectrum with the carbon at $\delta$ $110.3\left(\mathrm{CH}_{2}\right)$. This observation, together with a carbon signal at $\delta 151.6$ corresponding to a quaternary carbon, suggested the presence of an exomethylene group. The HMBC correlations of the two olefinic protons with C-17 $(\delta 52.5)$ and C-22 $(\delta$ 107.1), along with an NOE correlation with $\mathrm{H}-17(\delta 3.64)$ and $\mathrm{H}-23_{\mathrm{ax}}(\delta 1.88)$, supported a double bond between C-20 and C21.

Thus, the aglycone of $\mathbf{2}$ was elucidated as 20-dehydrohecogenin. The acetate derivative was synthesized by Tanabe and Peters $^{27}$ and is reported here for the first time from a natural source. Only one 20(21)-dehydrospirosteroid has been reported previously, and this was part of a saponin isolated from Cordyline stricta. ${ }^{28}$ Accordingly, the structure of 2 was established as (25R)-3 $\beta$-hydroxy- $5 \alpha$-spirost-20(21)-en-12-one 3-O-\{ $\alpha$-L-rhamnopyranosyl- $(1 \rightarrow 4)-O-\beta$-D-glucopyranosyl- $(1 \rightarrow$ $3)$ - $O$ - $[\beta$-D-glucopyranosyl- $(1 \rightarrow 3)-O-\beta$-D-glucopyranosyl- $(1 \rightarrow$ $2)]$ - $O$ - $\beta$-D-glucopyranosyl- $(1 \rightarrow 4)-O-\beta$-D-galactopyranoside $\}$. This compound has not been described previously, and its trivial name proposed is furcroside $\mathrm{B}$.

Compounds 1 and $\mathbf{2}$ were minor derivatives of furcreastatin (10), where furcroside B (2) would be an intermediate metabolite for the epimerization of furcreastatin (10) to furcroside A (1), thus suggesting that an oxido-reduction is involved in the metabolism of these compounds.

Compound 3 was isolated as a white, amorphous powder and gave the molecular formula $\mathrm{C}_{51} \mathrm{H}_{84} \mathrm{O}_{23}$ (HRTOFESIMS, $\mathrm{m} / z$ 1063.5310 $[\mathrm{M}-\mathrm{H}]^{-}$, calcd 1063.5325). The ${ }^{1} \mathrm{H}$ NMR spectrum of 3 was consistent with that of a spirostane saponin. A detailed study of the $1 \mathrm{D}$ and $2 \mathrm{D}$ NMR spectra led the aglycone moiety of compound 3 to be identified as tigogenin, the same as that in compounds 5-7. The ${ }^{1} \mathrm{H}$ NMR spectrum of 3 showed four anomeric signals at $\delta 4.88(\mathrm{~d}, J=7.7 \mathrm{~Hz}), 5.11$ $(\mathrm{d}, J=7.7 \mathrm{~Hz}), 5.14(\mathrm{~d}, J=6.9 \mathrm{~Hz})$, and $5.22(\mathrm{~d}, J=7.7 \mathrm{~Hz})$, and these were correlated in the HSQC spectrum with carbons at $\delta 102.3,105.0,106.2$, and 105.4, respectively. Sugar units were identified by $1 \mathrm{D}$-TOCSY and 1D-ROESY experiments involving selective excitation of each anomeric proton. Selective 1D-TOCSY experiments on the signals at $\delta 5.11,5.14$, and 5.22 showed a typical spin system for a $\beta$-glucopyranosyl moiety. The anomeric signal at $\delta 4.88$ showed a different TOCSY pattern, in which the coupling constants were consistent with trans-diaxial arrangements for $\mathrm{H}-1 / \mathrm{H}-2$ and $\mathrm{H}-2 / \mathrm{H}-3$. The relatively small coupling constant between $\mathrm{H}-3$ and $\mathrm{H}-4$ indicated the equatorial position of $\mathrm{H}-4$. The NOE correlations with $\mathrm{H}-3$ and $\mathrm{H}-5$ observed in the 1D-ROESY spectra indicated the presence of a $\beta$-galactopyranosyl moiety. Finally, HSQC and HSQC-TOCSY experiments showed unambiguously the complete correlations for proton and carbon signals of the tetrasaccharide portion. The absolute configurations of sugars were determined under the conditions described above. A study of the HMBC and ROESY correlations between $\mathrm{H}-1_{\mathrm{Glc}^{\prime \prime}}(\delta$ 5.22) and $\mathrm{C}-2_{\mathrm{Glc}^{\prime}}(\delta 87.2) / \mathrm{H}-2_{\mathrm{Glc}^{\prime}}(\delta 4.04), \mathrm{H}-1_{\mathrm{Glc}^{\prime}}(\delta 5.14)$ and $\mathrm{C}-2_{\mathrm{Glc}}(\delta 85.8) / \mathrm{H}-2_{\mathrm{Glc}}(\delta 4.12), \mathrm{H}-1_{\mathrm{Glc}}(\delta 5.11)$ and $\mathrm{C}-4_{\mathrm{Gal}}(\delta$ $80.8) / \mathrm{H}-4_{\mathrm{Gal}}(\delta 4.56)$, and $\mathrm{H}-1_{\mathrm{Gal}}(\delta 4.88)$ and $\mathrm{C}-3(\delta 77.3) / \mathrm{H}-$ $3(\delta 3.91)$ of tigogenin allowed the sequence of the sugar to be established. Thus, structure 3 was determined as tigogenin-3-O$\{\beta$-D-glucopyranosyl- $(1 \rightarrow 2)-O-\beta$-D-glucopyranosyl- $(1 \rightarrow 2)-O-\beta$ D-glucopyranosyl- $(1 \rightarrow 4)-O-\beta$-D-galactopyranoside $\}$. This saponin has not been described previously and has been named furcroside $\mathrm{C}$.

Compound 4 was isolated as a white, amorphous powder, with a molecular formula of $\mathrm{C}_{39} \mathrm{H}_{64} \mathrm{O}_{13}$ (HRTOFESIMS, $\mathrm{m} / z$ $763.4236[\mathrm{M}+\mathrm{Na}]^{+}$, calcd 763.4245). The ${ }^{1} \mathrm{H}$ NMR spectrum contained signals corresponding to a steroidal glycoside with two anomeric protons at $\delta 4.77(\mathrm{~d}, J=7.7 \mathrm{~Hz})$ and $5.07(\mathrm{~d}, J=$ $7.8 \mathrm{~Hz}$ ) and four methyl groups at $\delta 1.14(\mathrm{~d}, J=6.9 \mathrm{~Hz}), 0.67$ $(\mathrm{d}, J=5.4 \mathrm{~Hz}), 0.79(\mathrm{~s})$, and $0.79(\mathrm{~s})$. From a complete assignment of the ${ }^{1} \mathrm{H}$ and ${ }^{13} \mathrm{C}$ NMR signals of the aglycone moiety of 4, an oxygenation at C-3 was determined as the only functional group. A "cis" junction between the A and B rings of compound 4 was indicated by 2D-ROESY correlations observed from $\mathrm{H}-5(\delta 1.94)$ to $\mathrm{H}-4_{\mathrm{ec}}(\delta 1.66)$ and $\mathrm{H}-19(\delta$ $0.79)$, as well as from $\mathrm{H}-4_{\mathrm{ax}}(\delta 1.78)$ to $\mathrm{H}-7_{\mathrm{ax}}(\delta 0.92)$ and $\mathrm{H}-6_{\mathrm{ax}}$ $(\delta$ 1.69). Therefore, the aglycone moiety of 4 was identified as smilagenin. Analysis of the 1D-TOCSY, 1D-ROESY, and ${ }^{1} \mathrm{H}-{ }^{1} \mathrm{H}$ COSY spectra allowed the sugar units to be identified 


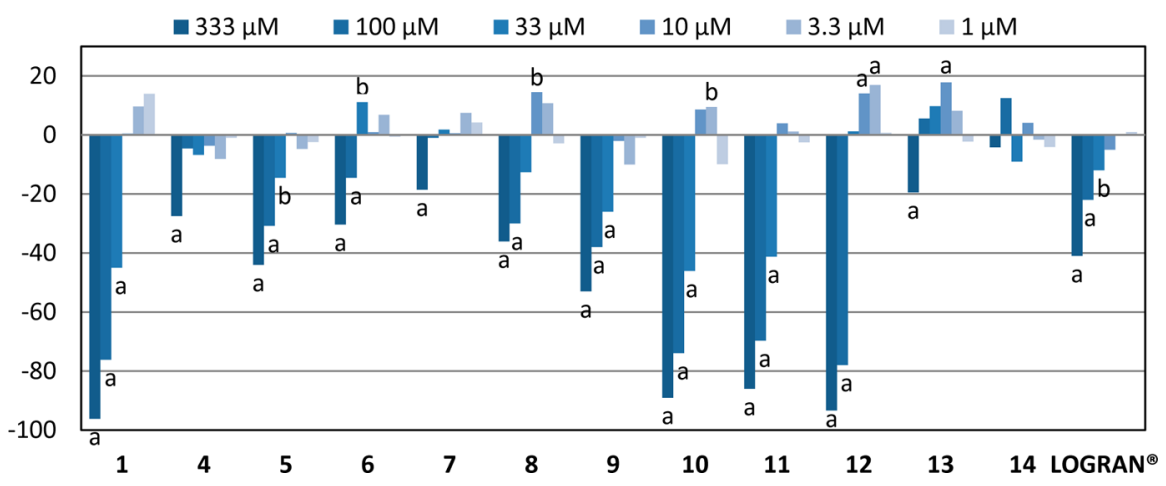

Figure 2. Effects of compounds 1 and 4-14 on root growth of Lactuca sativa L. Values are expressed as percentage difference from the control and are not significantly different with $p>0.05$ for the Welch's test. (a) Values significantly different with $p<0.01$. (b) Values significantly different with $0.01<p<0.05$.

as $\beta$-galactopyranoside and $\beta$-glucopyranoside. The connections of this diglycoside were established by $\mathrm{HMBC} / \mathrm{ROESY}$ correlations between $\mathrm{H}-1_{\mathrm{Glc}}(\delta 5.07)$ and $\mathrm{C}-6_{\mathrm{Gal}}(\delta 69.5) / \mathrm{H}_{2}-$ $6_{\mathrm{Gal}}(\delta 4.43,4.66)$ and between $\mathrm{H}-1_{\mathrm{Gal}}(\delta 4.77)$ and C-3 $(\delta$ $74.4) / \mathrm{H}-3(\delta 4.38)$ of smilagenin. Consequently, the structure of 4 (furcroside D) was formulated as smilagenin-3-O- $\{\beta$-Dglucopyranosyl-( $1 \rightarrow 6)-O-\beta$-D-galactopyranoside $\}$, which has not been described before.

The isolated pure compounds 1 and 4-14 were evaluated for their phytotoxic activity against Lactuca sativa L. as a standard target species ${ }^{9}$ at $333,100,33,10,3.3$, and $1 \mu \mathrm{M}$. The isolated compounds chlorogenin-3-O-[ $\beta$-D-glucopyranosyl $]-6-O-[\beta$-Dglucopyranoside $]^{18}$ and cantalasaponin- ${ }^{19}$ were excluded from this test because they had been assayed previously under identical conditions, ${ }^{7,8}$ and compounds 2, 3, and smilagenin-3-O-[ $\beta$-D-glucopyranosyl- $(1 \rightarrow 3)-O-\beta$-D-galactopyranoside $]^{16}$ could not be assayed due to the small amounts available.

The results of the bioassay are shown in Figure 2, where data are presented as percentage differences from the control. Positive values indicate stimulation and negative values represent inhibition of the studied parameters. The effects on root development were very significant, and the discussion is therefore focused on the root growth effects. Despite the lack of a high number of considered variables, a multivariate approach was performed, in order to facilitate the discussion and organize somehow the obtained data. The dendrogram resulting from hierarchical cluster analysis of the saponins tested is shown in Figure 3, in which two main clusters can be seen (S1 and S2).

Cluster S1 comprises compounds 1 and 10-12, which exhibited the best inhibition values. Comparison of the phytotoxic activities of $1\left(\mathrm{IC}_{50} 37.8 \mu \mathrm{M}\right), 10\left(\mathrm{IC}_{50} 50.7 \mu \mathrm{M}\right)$, and $11\left(\mathrm{IC}_{50} 51.4 \mu \mathrm{M}\right)$, all of which have a carbonyl group at $\mathrm{C}-12$, and $12\left(\mathrm{IC}_{50} 80.3 \mu \mathrm{M}\right)$, with a hydroxy group at $\mathrm{C}-12$, suggests that the presence of an oxygenated functional group at C-12 plays a key role in the activity displayed, with higher inhibition values obtained for compounds with a carbonyl group. In fact, compounds $5\left(\mathrm{IC}_{50} 355.6 \mu \mathrm{M}\right)$ and $6\left(\mathrm{IC}_{50}\right.$ 638.7 $\mu \mathrm{M}$ ), which have identical structures to 10 and 11 but lack oxygenated positions in the spirostanol, showed lower levels of inhibition.

The second cluster (S2) could be divided into two subclusters, S2a and S2b. The first included compounds 5, 8, and 9 and also exhibited good inhibition values (Table 3). Compounds $5\left(\mathrm{IC}_{50} 355.6 \mu \mathrm{M}\right)$ and $9\left(\mathrm{IC}_{50} 230.8 \mu \mathrm{M}\right)$ share the same chain of six sugars but have a different aglycone.

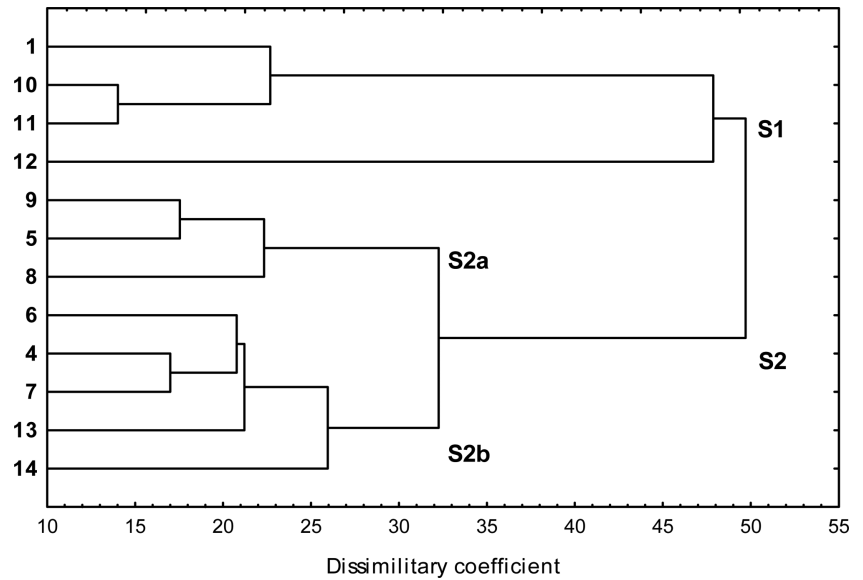

Figure 3. Dendogram of compounds tested in the phytotoxicity bioassay.

Table 3. Phytotoxicity of Compounds 1 and 4-14 on the Roots of Lactuca sativa

\begin{tabular}{lcl} 
compound & $\mathrm{IC}_{50}(\mu \mathrm{M})$ & \multicolumn{1}{c}{$r^{2}$} \\
$\mathbf{1}$ & 37.8 & 0.9915 \\
$\mathbf{4}$ & n.d. $^{a}$ & n.d. \\
$\mathbf{5}$ & $355.6^{b}$ & 0.9820 \\
$\mathbf{6}$ & $638.7^{b}$ & 0.9772 \\
7 & n.d. & n.d. \\
$\mathbf{8}$ & $354.9^{b}$ & 0.9386 \\
$\mathbf{9}$ & 230.8 & 0.9677 \\
$\mathbf{1 0}$ & 50.7 & 0.9084 \\
$\mathbf{1 1}$ & 51.4 & 0.9590 \\
$\mathbf{1 2}$ & 80.3 & 0.9203 \\
$\mathbf{1 3}$ & n.d. & n.d. \\
$\mathbf{1 4}$ & n.d. & n.d. \\
Logran & $439.7^{b}$ & 0.9949
\end{tabular}

$a_{\text {n.d: not determined. }}{ }^{b}$ The data were not adjusted to the doseresponse curve.

Compound 5 only has C-3 oxygenation, while compound 9 has another hydroxy group at position C-6 of the spirostanol. Compound $8\left(\mathrm{IC}_{50} 354.9 \mu \mathrm{M}\right)$ has a three-sugar glycosidic chain and a hydroxy group at position C-2. On the other hand, comparison of the data for compounds 7 (no significant inhibition) and $8\left(\mathrm{IC}_{50} 354.9 \mu \mathrm{M}\right)$, which differ only in the hydroxy group at $\mathrm{C}-2$, suggested a moderate influence of the hydroxy group when located in positions other than C-12. A 

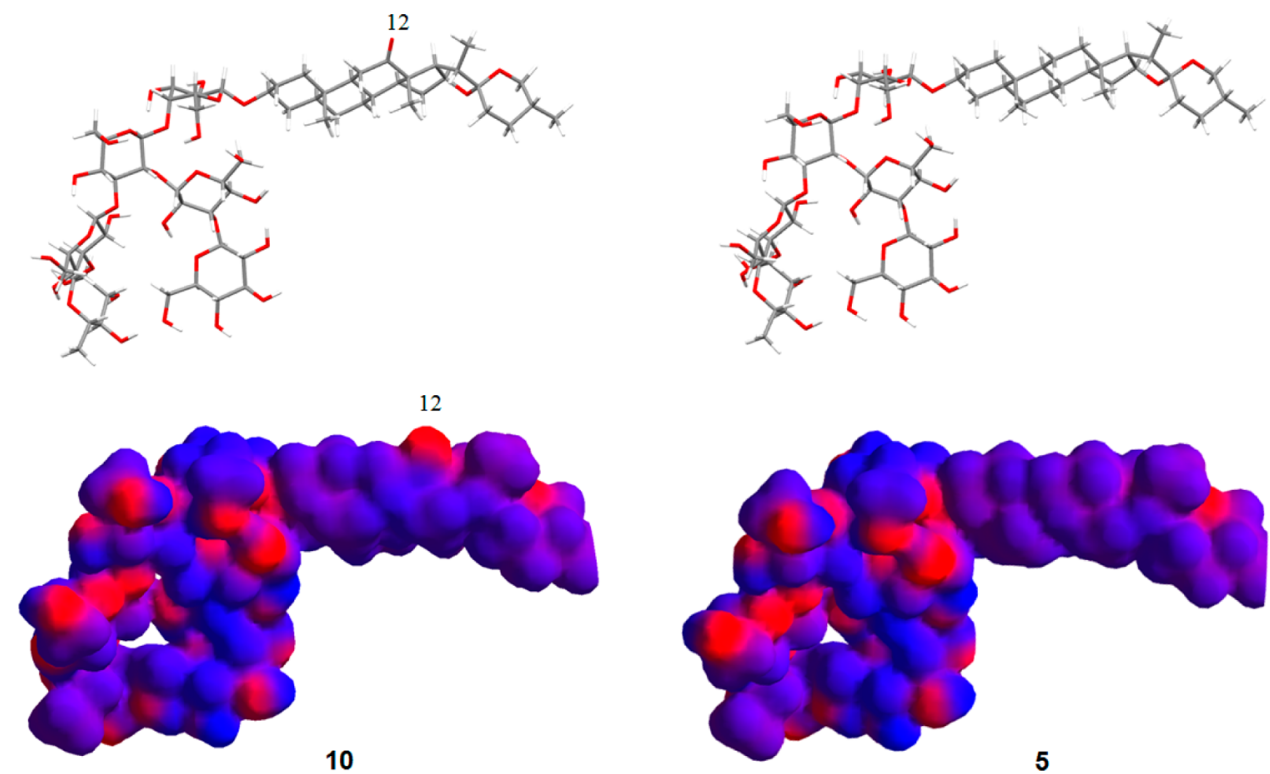

Figure 4. Comparison of the structures for compounds 10 and $\mathbf{5}$. The upper part of the figure depicts the lowest energy conformers. Below these is a representation of the spatial distribution of hydrophobic (blue) and hydrophilic (red) regions on the molecular surface.

detrimental effect on the activity was observed on decreasing the size of the oligosaccharide portion for compounds 5-7, which have the same aglycone moiety (tigogenin). The aforementioned data suggest, therefore, that the length of the glycoside chain and the presence of hydroxy groups in the aglycone could also be key factors for activity. Finally, subcluster S2b contained compounds 4, 6, 7, 13, and 14, which did not exhibit significant activity. This lack of activity is probably due to the lack of a long chain of sugars and/or the absence of an oxygenated functional group on the aglycone moiety.

Among the steroidal saponins tested, greater activity was observed for compounds with an oxygenated functional group at C-12. Molecular modeling was carried out with the aim of studying the influence of this feature in the molecular structure. A comparison of the minimized energy structures for compounds $10\left(\mathrm{IC}_{50} 50.7 \mu \mathrm{M}\right)$ and $\mathbf{5}\left(\mathrm{IC}_{50} 355.6 \mu \mathrm{M}\right)$, which differ only in a carbonyl group at $\mathrm{C}-12$, can be seen in Figure 4. It can be seen from the lowest energy conformers of the two compounds that the presence of the carbonyl group does not significantly alter the structure of the aglycone or sugar chain. Furthermore, it can be observed that the adopted conformation of the sugar moieties precludes interactions between the carbonyl group and the sugar units. This conformational study showed that the carbonyl group is accessible in space. Likewise, this functionalization results in a different distribution of hydrophobicity for ring $\mathrm{C}$ of the aglycone (Figure 4). Therefore, this change could affect the interaction with plant material and provides a possible explanation for the difference in activity observed.

In conclusion, on the basis of the results obtained and in agreement with our previous studies, ${ }^{7,8}$ the data obtained indicate that steroidal saponins with four or more sugar units in the glycosidic chain attached at C-3 can exhibit phytotoxic activity on $L$. sativa. In general, this activity increases with the length of the glycosidic chain and the presence of oxygenated functional groups in the aglycone moiety, especially when such a group is located at carbon 12, with 12-ketosaponins being the most active. The combination of these two features seems to be crucial for activity. Thus, the results outlined above may support a further investigation on the phytotoxic activity and mechanism of action of these saponins against other species of interest, especially weed species, before they can be considered as potential natural herbicides.

\section{EXPERIMENTAL SECTION}

General Experimental Procedures. Optical rotations were measured on a PerkinElmer model 241 polarimeter $(589 \mathrm{~nm}, 20$ $\left.{ }^{\circ} \mathrm{C}\right) .1 \mathrm{D}$ and 2D NMR spectra were recorded on an Agilent 600 DD2 spectrometer and an Agilent 500 DD2 spectrometer equipped with a 5 $\mathrm{mm}{ }^{1} \mathrm{H}\left\{{ }^{15} \mathrm{~N}-{ }^{31} \mathrm{P}\right\}$ PFG high-field inverse detection z-gradient probe. ${ }^{1} \mathrm{H}(599.772$ and $499.719 \mathrm{MHz})$ and ${ }^{13} \mathrm{C}(150.826$ and $125.666 \mathrm{MHz})$ NMR spectra were recorded in pyridine- $d_{5}$ at $25{ }^{\circ} \mathrm{C}$, and chemical shifts are given on the $\delta$ scale referenced to residual pyridine $\left(\delta_{\mathrm{H}} 8.70\right.$, $7.55,7.18$ and $\left.\delta_{\mathrm{C}} 149.84,135.50,123.48\right)$. Adiabatic pulse sequences using gradients were applied, and all 2D spectra, except for HMBC, were recorded in the phase-sensitive mode. Exact masses were measured on a UPLC-QTOF ESI (Waters Synapt G2, Manchester, UK) high-resolution mass spectrometer (HRTOFESIMS). Mass spectra were recorded in the negative- or positive-ion mode in the range $\mathrm{m} / \mathrm{z} 100-2000$, with a mass resolution of 20000 and an acceleration voltage of $0.7 \mathrm{kV}$. HPLC in the isocratic mode was performed on a Merck Hitachi apparatus equipped with a LaChrom (L-2490) refractive index detector and a LaChrom (L-2400) ultraviolet detector, using an analytical Phenomenex Gemini $\mathrm{C}_{18}$ column $(4.6 \times 250 \mathrm{~mm}$, i.d. $)$.

Plant Material. Leaves of Furcraea hexapetala were collected in March 2010 and were authenticated by botanist D. Alfredo Noa, in the neighborhood of Ranchuelo, in the province of Villa Clara, Cuba. A voucher specimen was deposited in the Herbarium Dr. Alberto Alonso Triana of the Universidad Central "Marta Abreu" de Las Villas, Cuba (number 10407 ULV).

Extraction and Isolation. Dried and powdered leaves $(1 \mathrm{~kg})$ were extracted three times with ethanol- $\mathrm{H}_{2} \mathrm{O}(7: 3)$ for $48 \mathrm{~h}$ by maceration at room temperature. The solvent was removed under reduced pressure, and the syrupy residue (16\%) was suspended in distilled water, defatted with $n$-hexane, and then extracted with $\mathrm{H}_{2} \mathrm{O}$-saturated $n$ - $\mathrm{BuOH}$. After removing the solvent, $15 \mathrm{~g}$ of the $n$ - $\mathrm{BuOH}$ extract ( $11 \%$ of an ethanolic extract) was purified by VLC on LiChrospher RP-18 and eluted with mixtures of $\mathrm{Me}_{2} \mathrm{CO}-\mathrm{H}_{2} \mathrm{O}$ to give nine fractions (F1: 1.35 g, F2: 4.69 g, F3: 1.97 g, F4: 1.27 g, F5: 2.45 g, F6: 1.14 g, F7: $0.36 \mathrm{~g}, \mathrm{~F} 8: 0.25 \mathrm{~g}$, and F9: $1.11 \mathrm{~g}$ ). 
Fraction F4 was subjected to MPLC on a Büchi 861 apparatus with a column filled with $40-63 \mu \mathrm{m}$ of LiChrospher RP-18, using $\mathrm{Me}_{2} \mathrm{CO}-$ $\mathrm{H}_{2} \mathrm{O}(1: 1)$ as mobile phase. Six milliliter fractions were collected and were checked by TLC on RP- $18 \mathrm{~F}_{254 \mathrm{~S}}$, developed with $\mathrm{MeOH}-\mathrm{H}_{2} \mathrm{O}$ (8:2), then sprayed with oleum reagent and heated at $150{ }^{\circ} \mathrm{C}$. Fractions with similar profiles were combined to give seven subfractions. Subfraction F4-3 was separated by HPLC on an analytical $\mathrm{C}_{18}$ column $(1 \mathrm{~mL} / \mathrm{min})$ and $\mathrm{MeOH}-\mathrm{H}_{2} \mathrm{O}(7: 3)$ or $\mathrm{CH}_{3} \mathrm{CN}-\mathrm{H}_{2} \mathrm{O}$ (3.5:6.5) as mobile phase to yield compounds 1 (4.9 $\mathrm{mg}), 2(2.5 \mathrm{mg}), 12(9.5 \mathrm{mg}), 13$ (8.6 mg), cantalasaponin-1 (8.1 mg), and $14(1.5 \mathrm{mg})$. Compound $\mathbf{1 0}(1.6 \mathrm{~g})$ was obtained as a precipitate from the $\mathrm{Me}_{2} \mathrm{CO}$ solution of F5. Fraction F6 was diluted in $\mathrm{MeOH}$ and filtered to remove the precipitate. The solution was then subjected to column chromatography (CC) on silica gel and eluted with a stepwise gradient of $\mathrm{CHCl}_{3}-\mathrm{MeOH}-\mathrm{H}_{2} \mathrm{O}$ (12:6:1 to 7:4:1) to yield 12 fractions. Subfractions containing the major saponins were chromatographed by HPLC under the same conditions as described above, using $\mathrm{Me}_{2} \mathrm{CO}-\mathrm{H}_{2} \mathrm{O}(6: 4)$ as the eluent, to afford compounds 5 $(3.8 \mathrm{mg}), \mathbf{6}(3.6 \mathrm{mg}), \mathbf{8}(3.5 \mathrm{mg}), \mathbf{1 1}(6.3 \mathrm{mg})$, smilagenin-3-O-[ $\beta$-Dglucopyranosyl-( $1 \rightarrow 3)-O-\beta$-D-galactopyranoside] $(1 \mathrm{mg})$, and chlorogenin-3-O-[ $\beta$-D-glucopyranosyl]-6-O-[ $\beta$-D-glucopyranoside $] \quad(6.0$ $\mathrm{mg})$. Finally, compounds $3(2.5 \mathrm{mg}), 4(3.5 \mathrm{mg})$, and $7(2.6 \mathrm{mg})$ were purified using $\mathrm{CH}_{3} \mathrm{CN}-\mathrm{H}_{2} \mathrm{O}$ (4.5:5.5) as mobile phase. Fraction F7 was subjected to $\mathrm{CC}$ on silica gel with $\mathrm{CHCl}_{3}-\mathrm{MeOH}-\mathrm{H}_{2} \mathrm{O}$ (12:6:1 to 7:4:1) and purified by HPLC on an analytical C-18 column with $\mathrm{Me}_{2} \mathrm{CO}-\mathrm{H}_{2} \mathrm{O}$ (5.5:4.5) to furnish 9 (4.1 mg).

Furcroside $A$ (1): white, amorphous solid; $[\alpha]^{20}-47.0(\mathrm{MeOH}, c$ 0.1 ); for ${ }^{1} \mathrm{H}$ and ${ }^{13} \mathrm{C}$ NMR data, see Tables 1 and 2; HRTOFESIMS, $m / z$ 1385.6241 $[\mathrm{M}-\mathrm{H}]^{-}$(calcd for $\mathrm{C}_{63} \mathrm{H}_{101} \mathrm{O}_{33}, 1385.6225$ ).

Furcroside $B(2)$ : white, amorphous solid; $[\alpha]^{20}{ }_{\mathrm{D}}-27.0(\mathrm{MeOH}, c$ 0.1); for ${ }^{1} \mathrm{H}$ and ${ }^{13} \mathrm{C}$ NMR data, see Tables 1 and 2; HRTOFESIMS, $m / z 1383.6047[\mathrm{M}-\mathrm{H}]^{-}$(calcd for $\mathrm{C}_{63} \mathrm{H}_{99} \mathrm{O}_{33}, 1383.6069$ ).

Furcroside C (3): white, amorphous solid; $[\alpha]_{\mathrm{D}}^{20}-35.5(\mathrm{MeOH}, c$ 0.1 ); for ${ }^{1} \mathrm{H}$ and ${ }^{13} \mathrm{C}$ NMR data, see Tables 1 and 2; HRTOFESIMS, $m / z 1063.5310[\mathrm{M}-\mathrm{H}]^{-}$(calcd for $\left.\mathrm{C}_{51} \mathrm{H}_{83} \mathrm{O}_{23}, 1063.5325\right)$.

Furcroside D (4): white, amorphous solid; $[\alpha]_{\mathrm{D}}^{20}-39.6(\mathrm{MeOH}, c$ 0.1 ); for ${ }^{1} \mathrm{H}$ and ${ }^{13} \mathrm{C}$ NMR data, see Tables 1 and 2; HRTOFESIMS, $m / z 763.4236[\mathrm{M}+\mathrm{Na}]^{+}$(calcd for $\mathrm{C}_{39} \mathrm{H}_{64} \mathrm{O}_{13} \mathrm{Na}, 763.4245$ ).

Acid Hydrolysis of Compounds 1-4 and Determination of Sugar Absolute Configuration. Compounds 1-4 (2 mg each) were treated with $2 \mathrm{M} \mathrm{HCl}$ in 1,4-dioxane- $\mathrm{H}_{2} \mathrm{O}(1: 1, \mathrm{v} / \mathrm{v}, 2 \mathrm{~mL})$ at 95 ${ }^{\circ} \mathrm{C}$ for $4 \mathrm{~h}$. After cooling, the solvent was removed under reduced pressure. The dried residue was suspended in water, and aglycones were extracted with ethyl acetate $(4 \times 2 \mathrm{~mL})$. The aqueous layer containing sugars was neutralized with Amberlite IR-45 ( $\mathrm{OH}^{-}$form), dried under reduced pressure, and stored prior to analysis. The absolute configurations of the monosaccharide constituents of compounds 1-4 were determined according to the method reported by Tanaka et al. ${ }^{21}$ with slight modifications. Sugars from each sample were dissolved in pyridine $(0.5 \mathrm{~mL})$ containing L-cysteine methyl ester hydrochloride $(1 \mathrm{mg})$ and heated at $60{ }^{\circ} \mathrm{C}$ for $1 \mathrm{~h}$; o-tolyl isothiocyanate $(2 \mu \mathrm{L})$ was then added, and the mixture was heated at $60{ }^{\circ} \mathrm{C}$ for $1 \mathrm{~h}$. Each reaction mixture was analyzed by reversed-phase HPLC using a Merck Hitachi apparatus equipped with a LaChrom (L2400) UV detector and analytical Phenomenex Gemini $\mathrm{C}_{18}$ column $\left(4.6 \times 250 \mathrm{~mm}\right.$, i.d): mobile phase: $\mathrm{CH}_{3} \mathrm{CN}-\mathrm{H}_{2} \mathrm{O}$ (2.5:7.5) containing $50 \mathrm{mM} \mathrm{H} \mathrm{PO}_{4}$; flow rate: $1 \mathrm{~mL} / \mathrm{min}$; detection: $\mathrm{UV}$ $(250 \mathrm{~nm})$. The derivatives of monosaccharides of D-galactose, Dglucose, and L-rhamnose, obtained from sugar hydrolysates, were identified by comparison of their retention times $\left(t_{\mathrm{R}}\right)$ with those of authentic samples (Sigma-Aldrich, Steinheim, Germany) treated in the same way as described above. The $t_{\mathrm{R}}$ of L-galactose, L-glucose, and Drhamnose was obtained by reaction of D-galactose, D-glucose, and Lrhamnose with D-cysteine methyl ester. ${ }^{21}$ Retention times of the derivatives were as follows: D-galactose $15.08 \mathrm{~min}$, L-galactose 16.00 min, D-glucose $17.30 \mathrm{~min}$, L-glucose $15.80 \mathrm{~min}$, L-rhamnose $28.36 \mathrm{~min}$, and D-rhamnose $20.23 \mathrm{~min}$.

Phytotoxicity Bioassay. Fractions were assayed at concentrations of 800,400 , and 200 ppm in etiolated wheat coleoptile assays. Pure compounds were bioassayed at $333,100,33,10,3.3$, and $1 \mu \mathrm{M}$ by phytotoxicity bioassays with the dicot L. sativa L. (lettuce) as standard target species. ${ }^{9}$ Both procedures were conducted under the conditions reported previously by us. ${ }^{7}$ Control samples (buffered aqueous solutions without any test compound) and the commercial herbicide Logran, a combination of $N$-(1,1-dimethylethyl)- $N^{\prime}$-ethyl-6-(methylthio)-1,3,5-triazine-2,4-diamine (Terbutryn, 59.4\%) and 2-(2-chloroethoxy)- $N$ - $\{[(4$-methoxy-6-methyl-1,3,5-triazin-2-yl)amino $]$ carbonyl\}benzene-sulfonamide (Triasulfuron, $0.6 \%$ ), were used as internal references ${ }^{9}$ and were tested under the same conditions as the samples.

The evaluated parameters in the phytotoxicity assay (germination rate, root length, and shoot length) were recorded using a Fitomed system, $^{29}$ which allowed automatic data acquisition and statistical analysis using its associated software. Data were analyzed statistically using Welch's test, with significance fixed at 0.01 and 0.05 . Results are presented as percentage differences from the control. Zero represents the control, positive values represent stimulation, and negative values represent inhibition. The concentration that resulted in a $50 \%$ inhibition ( $\mathrm{IC}_{50}$ values) was calculated from the dose-response curve.

The dendogram was obtained by using Statistica 7.0 software. ${ }^{30}$ Numerical clustering of bioassay data was carried out based on percentage differences from control, using the root length parameter. An average linkage was applied as an amalgamation criterion, and the distance measurement (dissimilarity coefficient) was based on Euclidean distances.

Method for Molecular Modeling Calculations. Calculations of minimum energy conformers were performed using PCModel 9.2 software. $^{31}$ The conformers created from molecular mechanics GMMX calculations were refined, and those with energies higher than $3.5 \mathrm{kcal} / \mathrm{mol}$ with respect to minima were not considered. The resultant conformers were used as the starting point for semiempirical calculations. These conformers were subsequently minimized using PM3 calculations by HyperChem 8.0.3 software. $^{32}$ 3D molecular models were constructed from lowest energy conformers using the same software.

\section{ASSOCIATED CONTENT}

\section{Supporting Information}

The Supporting Information is available free of charge on the ACS Publications website at DOI: 10.1021/acs.jnatprod.6b00702.

HRESIMS and 1D and 2D NMR spectra for compounds 1-4; complete ${ }^{1} \mathrm{H}$ and ${ }^{13} \mathrm{C}$ NMR data for compounds 5-8, 11-14, and smilagenin-3-O-[ $\beta$-D-glucopyranosyl$(1 \rightarrow 3)-O-\beta$-D-galactopyranoside $]$ that have not been reported to date completely (PDF)

\section{AUTHOR INFORMATION}

\section{Corresponding Author}

*Tel: +34 956 012770. Fax: +34 956 016193. E-mail: famacias@uca.es.

\section{Notes}

The authors declare no competing financial interest.

\section{ACKNOWLEDGMENTS}

This research was supported by the Ministerio de Economía y Competitividad (MINECO) (Project AGL2013-42238-R) and Consejería de Economía Innovación y Ciencia, Junta de Andalucía (P10 AGR-5822).

\section{REFERENCES}

(1) Álvarez de Zayas, A. Anales Inst. Biol. Univ. Nac. Autón. México, Ser. Bot. 1996, 67, 329-346.

(2) Blunden, G.; Carabot, A.; Jewers, K. Phytochemistry 1980, 19, 2489-2490. 
(3) Castellanos, L.; Fernández, A.; Ortega, I.; Soto, R.; Martin, C.

Rev. Protección Veg. 2011, 26, 122-124.

(4) Castellanos, L.; Fernández, A.; Ortega, I.; Guerra, J. O. J. Anim.

Plant Sci. 2011, 10, 1300-1305.

(5) Macías, F. A.; Guerra, J. O.; Simonet, A. M.; Nogueiras, C. M. Magn. Reson. Chem. 2007, 45, 615-620.

(6) Macías, F. A.; Guerra, J. O.; Simonet, A. M.; Pérez, A. J.; Nogueiras, C. M. Magn. Reson. Chem. 2010, 48, 350-355.

(7) Pérez, A. J.; Calle, J. M.; Simonet, A. M.; Guerra, J. O.; Stochmal, A.; Macías, F. A. Phytochemistry 2013, 95, 298-307.

(8) Pérez, A. J.; Simonet, A. M.; Calle, J. M.; Pecio, L.; Guerra, J. O.; Stochmal, A.; Macías, F. A. Phytochemistry 2014, 105, 92-100.

(9) Macías, F. A.; Castellano, D.; Molinillo, J. M. G. J. Agric. Food Chem. 2000, 48, 2512-2521.

(10) (a) Benidze, M. M.; Dzhikiya, O. D.; Pkheidze, T. A.; Kemertelidze, E. P.; Shashkov, A. S. Khim. Prir. Soedin. 1987, 4, 537542. (b) Ahmad, V. U.; Basha, A., Eds. Spectroscopic Data of Steroid Glycosides: Spirostanes, Bufanolides, Cardenolides; Springer: New York, 2006; Vol. 3, pp 1844-1845, 1899-1900.

(11) Shvets, S. A.; Latsterdis, N. V.; Kintia, P. K. Advances in Experimental Medicine and Biology. In Saponins, Used in Traditional and Modern Medicine; Plenum Press: New York, 1996; Vol. 404, pp $475-483$.

(12) (a) Shvets, S. A.; Naibi, A. M.; Kintya, P. K.; Shashkov, A. S. Khim. Prir. Soedin. 1995, 3, 391-395. (b) Ahmad, V. U.; Basha, A., Eds. Spectroscopic Data of Steroid Glycosides: Spirostanes, Bufanolides, Cardenolides; Springer: New York, 2006; Vol. 3, pp 1588-1589.

(13) Ohtsuki, T.; Koyano, T.; Kowithayakorn, T.; Sakai, S.; Kawahara, N.; Goda, Y.; Yamaguchi, N.; Ishibashi, M. Bioorg. Med. Chem. 2004, 12, 3841-3845.

(14) Itabashi, M.; Segawa, K.; Ikeda, Y.; Kondo, S.; Naganawa, H.; Koyano, T.; Umezawa, K. Carbohydr. Res. 2000, 323, 57-62.

(15) Kuroda, M.; Mimaki, Y.; Hasegawa, F.; Yokosuka, A.; Sashida, Y.; Sakagami, H. Chem. Pharm. Bull. 2001, 49, 726-731.

(16) Yokosuka, A.; Jitsuno, M.; Yui, S.; Yamazaki, M.; Mimaki, Y. J. Nat. Prod. 2009, 72, 1399-1404.

(17) Teng, R. W.; Jin, J. M.; Wang, D. Z.; Yang, C. R. Bopuxue Zazhi 2001, 18, 291-297.

(18) Sharma, S. C.; Sati, O. P. Phytochemistry 1982, 21, 1820-1821.

(19) Sati, O. P.; Pant, G. J. Nat. Prod. 1985, 48, 395-399.

(20) Yokosuka, A.; Sano, T.; Hashimoto, K.; Sakagami, H.; Mimaki, Y. Chem. Pharm. Bull. 2009, 57, 1161-1166.

(21) Tanaka, T.; Nakashima, T.; Ueda, T.; Tomii, K.; Kouno, I. Chem. Pharm. Bull. 2007, 55, 899-901.

(22) Agrawal, P. K. Magn. Reson. Chem. 2003, 41, 965-968.

(23) Tobari, A.; Teshima, M.; Koyanagi, J.; Kawase, M.; Miyamae, H.; Yoza, K.; Yakasaki, A.; Nagamura, Y.; Saito, S. Eur. J. Med. Chem. 2000, 35, 511-527.

(24) Wall, M. E.; Serota, S.; Eddy, C. R. J. Am. Chem. Soc. 1955, 77, $1230-1237$.

(25) Mimaki, Y.; Nagamura, O.; Sashida, Y.; Koike, K.; Nikaido, T.; Ohmoto, A.; Satomi, Y.; Nishino, H. Chem. Pharm. Bull. 1995, 43, 971-976.

(26) Minh, C. V.; Dat, N. T.; Dang, N. H.; Nam, N. H.; Ban, N. K.; Tuyen, N. V.; Huong, L. M.; Huong, T. T.; Kiem, P. V. Nat. Prod. Commun. 2009, 4, 1197-1200.

(27) Tanabe, M.; Peters, R. H. J. Org. Chem. 1970, 35, 1238-1239.

(28) Mimaki, Y.; Takaashi, Y.; Kuroda, M.; Sashida, Y. Phytochemistry

1997, 45, 1229-1234.

(29) Castellano, D.; Macías, F. A.; Castellano, M.; Cambronero, R. Span. Pat. No P9901565, 2001.

(30) STATISTICA, version 7.0; StatSoft Inc.: Tulsa, OK, USA, 2004.

(31) PCMODEL, version 9.2; Serena Software: Bloomington, IN, USA, 2006.

(32) HyperChem, version 8.0.3; HyperCube Inc.: Gainsville, FL, USA, 2007. 